\title{
TMS 2 Stoklar Standardında Yer Alan Stok Maliyeti Hesaplama Yöntemlerinin Gida Maddeleri Sanayi Sektöründeki İșletmelerde Kullanımı Üzerine Bir Araștırma
}

Gürbüz GÖKC̣EN' - Yasin CEBECi²

Makale Gönderim Tarihi: 02.10.2015

Makale Kabul Tarihi: 15.01.2016

\section{Öz}

Bu çalıșmada Türkiye Finansal Raporlama Standartları Seti içinde yer alan TMS 2 Stoklar Standardını uygulayan ve Gıda Maddeleri Sanayi Sektörü içerisinde faaliyet gösteren halka açık șirketlerin Kamuyu Aydınlatma Platformu'na sundukları finansal tablolarda, stok maliyeti hesaplama yöntemlerinden hangisinin ne oranda kullanıldığı ve ișletmelerin faaliyet sonuçları üzerine etkileri araștırılmıștır.

Anahtar Kelimeler: Türkiye Finansal Raporlama Standartları, TMS 2 Stoklar Standardı, Kamuyu Aydınlatma Platformu, stok maliyeti hesaplama yöntemleri.

\section{A Research About Utilization Of Inventory Cost Formulas Under TMS 2 Inventory Standards In Food Sector}

\section{Abstract}

In this study, utilization of inventory cost formulas in financial statements that are presented to Public Disclosure Platform by

Prof. Dr., Marmara Üniversitesi İșletme Fakültesi

2 Arș. Gör., Marmara Üniversitesi İșletme Fakültesi 
public companies which apply TMS 2 Inventory Standard in set of TFRS and operate in food sector; and its effects on operation results of companies have been investigated.

Keywords: Turkish Financial Reporting Standards, TMS 2 Inventory Standards, Public Disclosure Platform, Inventory Cost Formulas.

\section{Giriș}

Uluslararası ticari ilișkilerin gelișmesi, șirketlerin yerel düzenlemeler ile hazırladıkları finansal raporların, finansal tablo kullanıcılarının finansal bilgi ihtiyacına cevap verememesine neden olmaktadır. İșletmeler tarafından finansal tablo kullanıcılarına sunulan finansal bilginin faydalı olabilmesi için, ihtiyaca uygun olması ve açıklamayı amaçladığı konuları gerçeğe uygun bir șekilde sunması gerekmektedir.

Bu nedenlerle finansal raporlarda sunulacak bilgilerin farklı ülkelerdeki finansal tablo kullanıcıları tarafından değerlendirilmesinde ortak bir dile ihtiyaç duyulmaktadır. Muhasebede ve finansal raporlamadaki ortak dil ihtiyacı Uluslararası Muhasebe/ Finansal Raporlama Standartları'nın olușturulması gereğini ortaya çıkarmıștır.

Ülkemizde de uluslararası gelișmelere uyumu sağlamak için Kamu Gözetimi, Muhasebe ve Denetim Standartları Kurumu tarafından Türkiye Muhasebe ve Finansal Raporlama Standartları yayımlanmıs ve 6102 sayılı Türk Ticaret Kanunu ile finansal tabloların düzenlenmesinde bu standartları uygulama zorunluluğu getirilmiștir.

Özellikle imalat sanayinde faaliyet gösteren șirketlerin finansal tablolarında büyük yer tutan stoklar kalemi ile ilgili düzenlemeler TMS-2 Stoklar Standardında yer almaktadır. İmalat sanayinde stok tutarlarının yüksek olması nedeniyle stok maliyeti hesaplama yöntemlerinin seçimi finansal tabloları önemli ölçüde etkilemektedir. Çalıșmamızın ilk bölümünde finansal raporlama standartlarının önemi ve tarihsel gelișimi bir süreç halinde ele alınmıștır. İkinci bölümde TMS-2 Stoklar Standardında bahsedilen stok maliyeti 
hesaplama yöntemleri açıklanmıștır. Üçüncü bölümde ise Kamuyu Aydınlatma Platformu'nda (KAP) imalat sanayi sektörünün alt sektörü olan gıda maddeleri sanayinde faaliyet gösteren șirketlerin kullandıkları stok maliyeti hesaplama yöntemleri tespit edilerek sonuçlar değerlendirilmiștir.

\section{Finansal Raporlama Standartlarının Önemi ve Tarihsel Gelișimi}

Ülkeler arasındaki fiili sınırların adeta ortadan kalkması ile ișletmelerin uluslararası ticari faaliyetleri artmakta ve uluslararası sermaye hareketleri yoğunlașmaktadır. Uluslararası alanda meydana gelen bu gelișmeler kușkusuz kaliteli, ortak, karșılașıtıılabilir ve anlașılabilir finansal bilgi ihtiyacını beraberinde getirmektedir.

Finansal bilgi ihtiyacının karșılanmasında kullanılan en önemli araç finansal tablolardır. Finansal tablolar, muhasebe sistemi içinde kaydedilen ve toplanan bilgilerin, belirli zaman aralıklarıyla bu bilgileri kullanacak olanlara iletilmesini sağlayan araç, diğer bir ifade ile muhasebe dilidir (Akdoğan ve Tenker, 2010:4). Muhasebenin doğal uzantısı görünümündeki finansal tablolar, ișletme çalıșmalarının kontrol edilmesine, ișletmenin geleceğine yön verebilecek kararların alınmasına olanak sağlamaktadır (Yükçü ve Gönen, 2012:18).

Farklı ülkelerde yatırım yapmak isteyen çok uluslu ișletmeler standardize edilmiș ve her ülkede "aynı" denebilecek kadar yakınsamıș bir muhasebe tekdüzeliği istemektedirler (Elitaș, 2014:114). Ancak bir takım sosyal, ekonomik ve hukuki sebepler (Kızıl vd., 2013:3), kültürel farklılıklardan kaynaklanan farklı muhasebe kültürleri (Varıcı ve Özdemir, 2013:18) gibi nedenler söz konusu tekdüzeliği olumsuz etkilemektedir.

Söz konusu farklılıklar, finansal tablo unsurları için farklı tanımların kullanılmasına neden olmakta; örneğin, varlıklar, borçlar, özkaynaklar, gelir ve giderler farklı tanımlanmaktadır. Ayrıca söz konusu farklılıklar, finansal tablolarda yer alan kalemlerin muhasebeleștirilmesinde farklı kıstasların kullanılmasına ve bu kalemler için farklı ölçüm esaslarının benimsenmesine de yol açmaktadır. 
Finansal tabloların kapsamı ve bu tablolarda yer verilen açıklamalar da bu farklılıklardan etkilenmektedir (KGK, 2011:2).

Bu gelișmeler, ișletmeler tarafından gerçekleștirilen muhasebe ve finansal raporlama uygulamalarında farklı düzenlemeleri uyumlu hale getirebilmek amacıyla, özellikle birbiri ile ticari ilișki içindeki ülkelerin, aynı veya birbirleri ile uyumlu muhasebe standartlarını benimsemeleri gerekliliğini ortaya çıkarmaktadır (Tokay ve Deran, 2009:151) .

Finansal raporlama standartları olarak adlandırılan bu standartlar, finansal tabloları hazırlamak için gerekli ilkeleri, esasları, teamülleri, kuralları ve uygulamaları içeren normlar olarak tanımlanmakta ve finansal tabloların hazırlanmasına ilișkin ilkelerin uygulamaya geçirilmesini sağlayan esaslar ve yöntemlerden olușmaktadır (Stolowy vd, 2013:28).

Finansal raporlama standartlarının amaçları așağıdaki șekilde özetlenebilir:

- Borç verenlere, mevcut ve potansiyel yatırımcılara, ișletmeye kaynak sağlamak için alacakları kararlarda yararlı bilgiler sağlamak (Palea, 2013:21),

- Yurt dıșı yatırımların ülkeye gelmesinde ve ülkedeki ișletmelerin yurt dıșında yatırım yapmasında ihtiyaç duyulan ortak bir muhasebe dilinin olușmasını sağlamak (Akdoğan, 2012:30),

- Finansal nitelikteki benzer olayların, ifade edilme yönteminin benzerliğini sağlamak (Fidan ve Cinit, 2014:72),

- Finansal tabloların anlașılabilirliği, karșılaștırılabilirliği ve güvenilirliği artııılarak uluslararası yatırımcıların, ülkelerin sermaye piyasalarına yatıım yapmalarını kolaylaștırmak (Terzi vd, 2013:2),

- Denetim maliyetlerinin azaltılmasını sağlamak (Acar vd, 2009:4; aktaran Dalğar vd, $2011: 218$ ),

- Çokuluslu ișletmelerin anlașılması zor ve yabancı muhasebe uygulamalarının arkasına gizleyebilecekleri trans- 
fer fiyatlarının tespit edilebilmesini sağlamak (Acar vd, 2009:4; aktaran Dalğar vd, 2011:218).

Finansal raporlama standartlarının sağladığı tüm bu faydalar nedeniyle artık çok uluslu ișletmelerin yatırımını yapmadan önce - ülkenin muhasebe standartlarının Uluslararası Muhasebe ve Finansal Raporlama Standartları ile uyumlu olup olmadığını sorgulamasına ve belki yakın bir zamanda bu uygulamaya geçmemiș, bir ülkenin yatırım yapılmayacak ülkeler arasında gösterilmesine neden olacaktır. (Elitaș, 2014:115).

Uluslararası muhasebe standartlarının olușturulması konusunda ilk çalıșmalar 1960'larda bașlamıș ve bu konunun bir örgüt (komite) tarafından yürütülmesine yönelik somut öneriler, ilk defa 1972 yılında Sydney'de yapılan 10. Uluslararası Muhasebeciler Kongresi'nde gündeme getirilerek 1973 yllında Kanada, Fransa, Almanya, Japonya, Meksika, Hollanda, İngiltere, İrlanda ve Amerika'daki profesyonel muhasebe kurumları tarafından yapılan bir anlașma ile Uluslararası Muhasebe Standartları Komitesi (International Accounting Standards Committee-IASC) kurulmuștur.

Komitenin temel amacı, denetlenmiș hesapların ve finansal raporların sunulmasında dikkate alınması gerekli temel standartları belirleyip, bunları kamuya açık bir șekilde yayınlamak ve böylece bu hesapların dünya çapında kabul edilme ve dikkate alınma olanağını arttırmaktır.

Uluslararası Muhasebe Standartları Komitesi, 2001 yılında Uluslararası Muhasebe Standartları Kurulu (International Accounting Standards Board-IASB) olarak yeniden yapılandırılmıștır.

Ardından, Amerikan Genel Kabul Görmüș Muhasebe Illkeleri (US GAAP) ve Uluslararası Finansal Raporlama Standartları (UFRS) arasındaki farklılıkların giderilmesi konusunda 18 Eylül 2002 tarihinde FASB ve IASB arasında yapılan Norwalk Anlașması ile bütün dünyanın kabul edeceği ortak bir muhasebe dilinin sağlanması için en önemli adımlardan biri atılmıștır (Akdoğan ve Tenker, 2010:15).

Finansal raporlama standartlarının hangi kurum tarafından olușturulacağı ülkeden ülkeye farklılık göstermektedir. Muhasebe- 
ye vergi amaçlı ihtiyaç duyulan ülkelerde muhasebe standartlarının devlet tarafından belirlenme eğilimi yüksek iken; muhasebeyi daha çok bir finansal bilgi sistemi olarak gören ve sermaye piyasalarının gelișmiș olduğu ülkelerde ise standartlar özel kesim tarafından belirlenme eğilimindedir (Elitaș vd, 2011:2).

Türkiye'de muhasebe standartlarının olușturulma süreci ise, TÜRMOB tarafından 9 Șubat 1994 tarihinde, finansal tabloların ihtiyaca uygun, karșılaștırılabilir ve anlașılabilir nitelikte olmalarını sağlayacak ulusal muhasebe standartları ile muhasebe meslek mensuplarının, denetim faaliyetlerini disiplinli yürütebilmeleri için ulusal denetim standartlarını saptamak ve yayınlamak üzere Türkiye Muhasebe ve Denetim Standartları Kurulu'nun (TMUDESK) kurulmasıyla bașlamıștır. Ardından, 18 Aralık 1999 tarih ve 4487 sayılı kanunla Sermaye Piyasası Kanunu'nda değișiklik yapan Kanun'un Ek 1. maddesi ile Türkiye Muhasebe Standartları Kurulu (TMSK) kurulmuștur (Gökçen vd, 2011 1:9). TMUDESK tarafından yayınlanan standartlar, TMSK tarafından yapılan çalıșmalara önemli bir alt yapı olușturmuștur.

Türkiye'de UFRS'ye uyum için olușturulan bu kurul Nisan 2006'ya kadar UMS ve UFRS'leri Türkçeye çevirerek yayınlamıștır. 2 Kasım 2011 tarihinde yayınlanan 660 sayılı Kanun Hükmünde Kararname ile Kamu Gözetimi, Muhasebe ve Denetim Standartları Kurumu'nun kurulmasıyla TMSK'nın görevi sona ermiștir (Șavlı, 2014:9). TFRS/TMS'leri yayınlama yetkisi verilen KGK, münferit ve konsolide finansal tabloların hazırlanmasında TFRS (TMS)'yi uygulaması gereken kurulușları açıklayarak, kapsamının her yıl genișletileceği ve belirli bir süre içinde bütün büyük șirketlerin denetiminin TFRS'ler esas alınarak yapılacağını belirtmiștir (Șavlı, 2014:13-17).

\section{TMS 2 Stoklar Standardındaki Stok Maliyeti Hesaplama Yöntemleri}

Stokların muhasebeleștirilmesinde en önemli problemlerden biri, stok maliyetinin dönem içinde satılan ve raporlama gününde elde kalan stoklar arasında dağıtımıdır. Farklı stok kalemlerinin maliyetleri dönem içinde değiștiğinde, maliyet hesaplaması rapor- 
lanan karı ve varlık değerlerini etkilemekte kullanılabilir (Alfredson $\mathrm{vd}, 2005: 263)$.

Stokların maliyeti, tüm satın alma maliyetleri, dönüștürme (șekillendirme) maliyetleri ve stokların mevcut durumuna ve konumuna getirilmesi için katlanılan diğer maliyetlerden olușur (Gökçen vd, $2011: 128)$. Stok maliyeti bilgisi; ürün fiyatlaması, ürün kârlıı̆ı, üretim maliyeti kontrolü ve stratejik rekabet politikalarının belirlenmesi gibi amaçlar için değerli bir bilgidir (Badem ve Özbek, 2013:66).

TMS 2 Stoklar Standardına göre stoklar, maliyet ve net gerçekleșebilir değerden düșük olanı ile değerlenir (Gökçen vd, 2011:128). Net gerçekleșebilir değer; ișin normal seyri içinde tahmin edilen satıș fiyatından değișken satıș giderlerinin düșülmesi ile elde edilen tutardır (Stolowy vd, 2013:330).

TMS 2 Stoklar Standardına göre stokların maliyeti; gerçek parti maliyet yöntemi, ilk giren ilk çıkar yöntemi ve ağırlıklı ortalama maliyet yöntemlerinden biri ile hesaplanabilir (KGK, 2015:paragraf 23-27). Standartta alternatif yöntemlerden hangisinin öncelikle kullanılması gerektiği belirtilmemiștir (Özbek, 2008:92). İșletmelerin söz konusu yöntemlerden fiili iș akıșlarına en uygun yöntemi benimsemeleri gerekir (Bahadır, 2012:56). Ancak ișletme benzer özelliklere ve benzer kullanıma sahip tüm stoklar için aynı maliyet hesaplama yöntemini kullanır. Türü veya kullanım alanları itibarıyla farklı olan stoklar için, farklı maliyet hesaplama yöntemleri kullanılabilir (KGK, 2015:paragraf 25).

Standarda göre normal koșullarda birbiri ile ikame edilemeyen stoklar ile özel projeler için üretilen veya satın alınan mal veya hizmetlerin maliyeti için "gerçek parti maliyeti yöntemi"; bunlarında dıșında kalan stokların maliyeti için ise "ağırlıklı ortalama maliyet" ya da "ilk giren ilk çıkar" (FIFO) yöntemlerinden biri kullanilabilir (Uyar, 2009:138).

Standartta, daha önceden stok değerlemesi açısından kullanımına imkân tanınan son giren ilk çıkar (LIFO) yönteminin, standardın 1 Ocak 2005 tarihi itibariyle yürürlüğe giren versiyonunda, stok akıșlarının sunumu açısından güvenilir bulunmama- 
sı nedeniyle kullanımının yasaklanmasına karar verilmiștir (Uyar, 2009: 139).

TMS 2 Stoklar standardı esas itibariyle muhasebe sistemine bir değișiklik getirmemektedir. Bunun nedeni stok maliyetlerinin muhasebeleștirilmesinde bazı farklılıkların olmasına karșın VUK'nun stok değerlemesine ilișkin hükümlerinin TMS 2' den çok da farklı olmamasıdır (Akin ve Kurșunel, 2010:327).

\subsection{Gerçek Parti Maliyet Yöntemi}

Normal șartlarda birbirleri ile ikame edilemeyen stok kalemleri ile özel projeler için üretilen veya satın alınan mal veya hizmetlerin maliyeti, her bir varlığa ilișkin özel maliyeti dikkate alınarak belirlenir. Bu yöntemin, belirli bir proje için ayrılan stoklara ilișkin olarak, bu stokların satın alınmıș veya üretilmiș olmasına bakılmaksızın kullanılması uygundur (Gökçen vd, 2011:131).

Ancak uygulamada bu yöntem nadiren kullanılır. Çünkü stok miktarı çok yüksek miktarlarda olduğundan tüm stokların gerçek maliyetinin belirlenmesi imkânsızdır (CA Pakistan, 2015:19).

Gerçek parti maliyeti yöntemi genellikle büyük tip stoklar için uygulama alanı bulan bir yöntemdir. Bu yöntemde her bir stokun hangi fiyattan alındığı rahatıkla tespit edilebilmektedir. Dolayısıyla dönem sonunda kalan veya elden çıkarılan stokların hangi fiyatlı alıștan yapıldığı kolayca saptanabilmektedir (Özbek, 2008:92).

\subsection{FIFO (illk Giren Illk Çıkar) Yöntemi}

Bu yöntemde ilk satın alınan veya üretilen stok kaleminin ilk satıldığı ve dönem sonunda stokta kalan kalemlerin en son satın alınanlar veya üretilenlerden olduğu varsayılır (Gökçen vd, 2011:131).

Bașka bir ifade ile satıș ișlemi gerçekleștiğinde ișletmeye en önce giren stok kalemlerinden çıkıș yapılacağından; dönem sonunda kalan stoklar, en son giriși yapılan stok kalemlerinin fiyatları üzerinden değerlendirilmektedir (Uyar, 2009:139). 
Sürekli fiyat artıșlarının yașandığı bir ortamda bu yöntemin uygulanması ile elden çıkarılan stokların maliyeti düșük, dönem sonunda elde kalan stokların maliyeti ise yüksek olacaktır (Özbek, 2008:95).

Bu yöntem özellikle çabuk bozulan gıdalarda veya modası hızlı geçen ürünlerde fiziksel stok hareketlerini en iyi yansıtan yöntemdir (Alfredson vd, 2005:264).

\subsection{Ağırlıklı Ortalama Maliyet Yöntemi}

Bu yöntemde, her bir stok kaleminin maliyeti, dönem bașındaki benzer varlıkların ağırlıklı ortalama maliyeti ile dönem içinde satın alınan veya üretilen benzer varlıkların maliyetinin ağırlıklı ortalamasının alınması suretiyle hesaplanır. Ortalama, ișletmenin iș akıșına bağlı olarak, periyodik bazda (dönem sonu ağırlıklı ortalama maliyet yöntemi) veya her bir ek alım/üretim sonrasında (hareketli ağırlıklı ortalama maliyet yöntemi) hesaplanabilir (Gökçen vd, 2011:131).

Ağırlıklı ortalama maliyet yöntemi, hesaplanma zamanına göre iki șekilde uygulanmaktadır. Bazı ișletmeler ortalamalarını maliyet dönemi sonunda hesaplamaktadır. Dönem sonu ağılıklı ortalama maliyet yöntemi olarak anılan bu yöntemde stok maliyeti, dönem bașı stoklar ile dönem içinde değișik partilerde giren stokların toplam maliyetinin, toplam maliyete konu olan toplam stok miktarına bölünmesi ile bulunur (Özbek, 2008:93).

Yalnızca dönem sonunda değil her bir stok girișinde farklı bir ortalama fiyata ulașılması ise hareketli ağırlıklı ortalama maliyet yöntemi ile mümkündür. Yeni stok girdiğinde yeni stokun tutarına eldeki stokların tutarı eklenir, bulunacak rakam formülün payını olușturmaktadır. Bu tutara; yeni stok miktarı ve eldeki stok miktarının toplam rakamı bölünür (Özbek, 2008:94).

Ağırlıklı ortalama maliyet yöntemi, özellikle fiyat dalgalanmalarının görüldüğü durumlarda farklı tarihlerde edinilmiș olan malları ortalama bir değer üzerinden değerlediğinden, adil ve güvenilir bir yöntem olarak görülmektedir (Uyar, 2009:138). 


\section{Araștırma}

\subsection{Araștırmanın Amacı}

Bu araștırmanın amacı; Gıda Maddeleri Sanayi Sektörü'ndeki șirketlerin stoklar için hangi stok maliyeti hesaplama yöntemlerini kullandığının tespit edilmesidir.

\subsection{Araștırmanın Kapsamı ve Yöntemi}

Araștırma, Kamuyu Aydınlatma Platformu'nda (KAP) imalat sanayi sektörünün alt sektörü olan gıda maddeleri sanayinde faaliyet gösteren șirketleri kapsamaktadır. Söz konusu șirketlerin KAP'a bildirdiği 2014 yılı finansal tabloları incelenerek kullandıkları stok maliyeti hesaplama yöntemleri tespit edilmiștir.

\subsection{Araștırmanın Bulguları ve Analizi}

Gıda maddeleri sanayi sektöründe KAP'a bildirim yapan 28 adet șirket bulunmaktadır. Bu șirketler Tablo 1'de gösterilmiștir.

\section{Tablo 1. KAP'a Bildirim Yapan Gıda Maddeleri Sanayi Șirketleri}

\begin{tabular}{|c|l|l|}
\hline & ȘiRKET KODU & ȘiRKET ADI \\
\hline 1 & ALYAG & ALTINYAĞ \\
\hline 2 & AVOD & A.V.O.D. GIDA VE TARIM \\
\hline 3 & BANVT & BANViT \\
\hline 4 & CCOLA & COCA COLA IÇECEK \\
\hline 5 & DARDL & DARDANEL \\
\hline 6 & EKIZ & EKIZ KIMYA \\
\hline 7 & ERSU & ERSU GIDA \\
\hline 8 & FRIGO & FRIGO PAK GIDA \\
\hline 9 & KRSAN & KARSUSAN SU ÜRÜNLERI SAN. \\
\hline 10 & KENT & KENT GIDA \\
\hline 11 & KERVT & KEREVITAS GIDA \\
\hline 12 & KNFRT & KONFRUT GIDA \\
\hline 13 & KRSTL & KRISTAL KOLA \\
\hline 14 & MANGO & MANGO GIDA \\
\hline 15 & MERKO & MERKO GIDA \\
\hline 16 & MRTGG & MERT GIDA \\
\hline 17 & OYLUM & OYLUM SINAI YATIRIMLAR \\
\hline
\end{tabular}




\begin{tabular}{|l|l|l|}
\hline 18 & PENGD & PENGUEN GIDA \\
\hline 19 & PETUN & PINAR ET VE UN \\
\hline 20 & PINSU & PINAR SU \\
\hline 21 & PNSUT & PINAR SÜT \\
\hline 22 & SELGD & SELÇUK GIDA \\
\hline 23 & TATGD & TAT GIDA \\
\hline 24 & TKURU & TAZE KURU GIDA \\
\hline 25 & TUKAS & TUKASS \\
\hline 26 & ULUUN & ULUSOY UN SANAYI \\
\hline 27 & ULKER & ÜLKER BISKÜVI \\
\hline 28 & VANGD & VANET GIDA \\
\hline
\end{tabular}

Tablo 1'de gösterilen 28 șirketin KAP'a bildirdiği 2014 yılı finansal tabloları incelenmiștir. Buna göre Tablo 2'de șirketlerin son üç yılda TMS 2'ye göre kullandıkları stok maliyeti hesaplama yöntemleri gösterilmiștir.

Tablo 2. KAP'a Bildirim Yapan Gıda Maddeleri Sanayi Șirketlerinin Kullandıkları Stok Maliyeti Hesaplama Yöntemleri

\begin{tabular}{|l|l|c|c|c|}
\hline ȘiRKET KODU & ȘíRKET ADI & $\mathbf{2 0 1 4}$ & $\mathbf{2 0 1 3}$ & $\mathbf{2 0 1 2}$ \\
\hline ALYAG & ALTINYAĞ & $\mathrm{AOM}^{3}$ & $\mathrm{AOM}$ & $\mathrm{BY}^{4}$ \\
\hline AVOD & A.V.O.D. GIDA VE TARIM & AOM & AOM & AOM \\
\hline BANVT & BANVIT & AOM & AOM & AOM \\
\hline CCOLA & COCA COLA İCECEK & AOM & AOM & AOM \\
\hline DARDL & DARDANEL & AOM & AOM & AOM \\
\hline EKIZ & EKIZ KIMYA & AOM & AOM & AOM \\
\hline ERSU & ERSU GIDA & BY & AOM & AOM \\
\hline FRIGO & FRiGO PAK GIDA & BY & BY & HOM \\
\hline KRSAN & KARSUSAN SU ÜRÜNLERI SAN. & FIFO & FIFO & FIFO \\
\hline KENT & KENT GIDA & AOM & AOM & AOM \\
\hline KERVT & KEREVITAȘ GIDA & AOM & AOM & AOM \\
\hline KNFRT & KONFRUT GIDA & AOM & AOM & AOM \\
\hline KRSTL & KRiSTAL KOLA & HOM & HOM & HOM \\
\hline MANGO & MANGO GIDA & FIFO & FIFO & FIFO \\
\hline
\end{tabular}

3 AOM: Ağırlıklı Ortalama Maliyet

4 BY: Bilgi Yok

5 HOM: Hareketli Ortalama Maliyet 


\begin{tabular}{|l|l|c|c|c|}
\hline MERKO & MERKO GIDA & AOM & AOM & AOM \\
\hline MRTGG & MERT GIDA & FIFO & FIFO & FIFO \\
\hline OYLUM & OYLUM SINAI YATIRIMLAR & BY & HOM & HOM \\
\hline PENGD & PENGUEN GIDA & HOM & HOM & HOM \\
\hline PETUN & PINAR ET VE UN & AOM & AOM & AOM \\
\hline PINSU & PINAR SU & AOM & AOM & AOM \\
\hline PNSUT & PINAR SÜT & AOM & AOM & AOM \\
\hline SELGD & SELCCUK GIDA & FIFO & HOM & AOM \\
\hline TATGD & TAT GIDA & BY & BY & BY \\
\hline TKURU & TAZE KURU GIDA & HOM & HOM & AOM \\
\hline TUKAS & TUKASS & HOM & HOM & HOM \\
\hline ULUUN & ULUSOY UN SANAYI & BY & BY & BY \\
\hline ULKER & ÜLKER BISKÜVI & AOM & AOM & AOM \\
\hline VANGD & VANET GIDA & AOM & AOM & AOM \\
\hline
\end{tabular}

Tablo 2'de görüldüğü üzere 2012 yılında șirketlerden 17'si stok maliyetini hesaplarken ağırlıklı ortalama maliyet yöntemini kullanırken, 5'i hareketli ortalamayı, 3'ü ise ilk giren ilk çıkar maliyet yöntemini kullanmıștır. Șirketlerden $3^{\prime}$ ünde ise finansal tablolarında hangi stok maliyeti hesaplama yöntemini kullandığına ilișkin bilgi bulunmamaktadır.

2013 yılında șirketlerden 16'sı stok maliyetini hesaplarken ağırlıklı ortalama maliyet yöntemini kullanırken, 6'sı hareketli ortalamayı, 3'ü ise 2012 yılı ile benzer șekilde ilk giren ilk çıkar yöntemini kullanmıștır. Șirketlerden 3 'ünde ise finansal tablolarında hangi stok maliyeti hesaplama yöntemini kullandığına ilișkin bilgi bulunmamaktadır.

2014 yılında șirketlerden 15'i stok maliyetini hesaplarken ağırlıklı ortalama maliyet yöntemini kullanırken, 4'ü hareketli ortalamayı, 4'ü ise ilk giren ilk çıkar yöntemini kullanmıștır. Șirketlerden 5 'inde ise finansal tablolarında hangi stok maliyeti hesaplama yöntemini kullandığına ilișkin bilgi bulunmamaktadır.

Veriler incelendiğinde iki șirketin stok maliyeti hesaplama yöntemini değiștirdiği görülmektedir. Selçuk Gıda 2012 yılında ağırlıklı ortalama maliyet yöntemini kullanırken, 2013 yılında hareketli ortalama maliyet yöntemine geçmiș, 2014 yılında da ilk giren ilk çıkar maliyet yöntemini kullanmaya bașlamıștır. Yöntem 
değișikliği yapan bir diğer șirket olan Taze Kuru Gıda ise 2012 yılında ağırlıklı ortalama maliyet yöntemini kullanırken 2013 yılında hareketli ortalama maliyet yöntemine geçmiștir. Șirketlerin kullandığı stok maliyeti hesaplama yöntemlerinin yüzdesel dağılımı ise șekil 1'de gösterilmiștir.

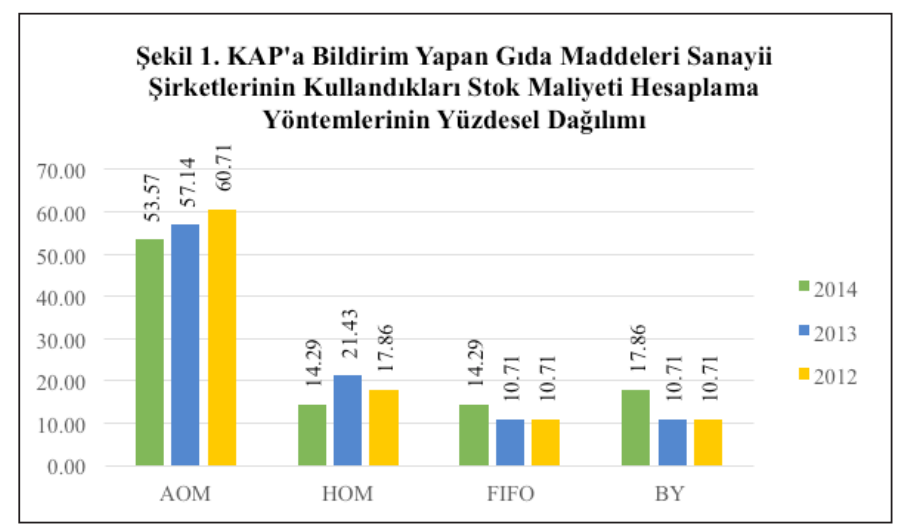

Șekil 1'de görüldüğü üzere, ağırlık ortalama maliyet yöntemini kullanan șirketler 2012 yılında \%60,71, 2013 yılında $\% 57,14$ ve 2014 yılında \%53,57 ile azalan bir seyir izlemektedir. Șirketlerin hareketli ortalama maliyet yöntemini kullanım oranı 2012 yılında \%17,86, 2013 yilında \%21,43 ve 2014 yılında ise \%14,29'dur. Șirketlerin ilk giren ilk çıkar yöntemini kullanım oranı ise 2012 ve 2013 yıllarında \%10,71 iken 2014 yılında $\% 14,29$ 'a yükselmiștir.

TMS-2 Stoklar Standardına göre stokların, maliyet değeri ya da net gerçekleșebilir değerin düșük olanı ile değerlendirilmesi gerekmektedir. Buna göre șirketler dönem sonunda normal piyasa șartlarındaki tahmini satıș fiyatından ürünün tamamlanma ve satıș giderlerinin çıkarılması sonucu hesaplanan net gerçekleșebilir değer ile maliyet değerini karșılaștıracak, net gerçekleșebilir değerin maliyet değerinden daha düșük olması durumunda bu değeri kullanarak aradaki fark kadar da stok değer düșüklüğü karșilığı ayıracaktır. Tablo $3^{\prime}$ te KAP'a bildirim yapan gida maddeleri sanayi șirketlerinin stok değerlemesini hangi değer üzerinden yaptığı yıllar itibari ile gösterilmiștir. 


\section{Tablo 3. KAP'a Bildirim Yapan Gida Maddeleri Sanayi Șirketlerinin Stok Değerlemesi}

\begin{tabular}{|c|c|c|c|c|}
\hline ȘiRKET KODU & ȘÍRKET ADI & 2014 & 2013 & 2012 \\
\hline ALYAG & ALTINYAĞ & $N^{\prime} D^{6}$ & NGD & NGD \\
\hline AVOD & A.V.O.D. GIDA VE TARIM & $\mathrm{MD}^{7}$ & MD & MD \\
\hline BANVT & BANVIT & NGD & NGD & NGD \\
\hline CCOLA & COCA COLA ICCECEK & NGD & NGD & NGD \\
\hline DARDL & DARDANEL & MD & MD & MD \\
\hline EKIZ & EKIZ KIMYA & $M D$ & MD & $M D$ \\
\hline ERSU & ERSU GIDA & $M D$ & NGD & NGD \\
\hline FRIGO & FRIGO PAK GIDA & NGD & NGD & NGD \\
\hline KRSAN & KARSUSAN SU ÜRÜNLERI SAN. & $M D$ & $M D$ & $M D$ \\
\hline KENT & KENT GIDA & NGD & NGD & NGD \\
\hline KERVT & KEREVITAȘ GIDA & NGD & NGD & NGD \\
\hline KNFRT & KONFRUT GIDA & NGD & NGD & NGD \\
\hline KRSTL & KRISTAL KOLA & NGD & NGD & NGD \\
\hline MANGO & MANGO GIDA & $M D$ & $M D$ & $M D$ \\
\hline MERKO & MERKO GIDA & NGD & NGD & NGD \\
\hline MRTGG & MERT GIDA & NGD & NGD & NGD \\
\hline OYLUM & OYLUM SINAI YATIRIMLAR & $M D$ & MD & MD \\
\hline PENGD & PENGUEN GIDA & NGD & NGD & NGD \\
\hline PETUN & PINAR ET VE UN & $M D$ & MD & MD \\
\hline PINSU & PINAR SU & MD & $M D$ & MD \\
\hline PNSUT & PINAR SÜT & $M D$ & $M D$ & MD \\
\hline SELGD & SELÇUK GIDA & NGD & NGD & NGD \\
\hline TATGD & TAT GIDA & NGD & NGD & NGD \\
\hline TKURU & TAZE KURU GIDA & MD & MD & MD \\
\hline TUKAS & TUKAȘ & NGD & NGD & NGD \\
\hline ULUUN & ULUSOY UN SANAYI & NGD & NGD & NGD \\
\hline ULKER & ÜLKER BISKÜVI & NGD & NGD & NGD \\
\hline VANGD & VANET GIDA & NGD & MD & MD \\
\hline
\end{tabular}

6 NGD: Net Gerçekleșebilir Değer

7 Maliyet Değeri 
Tablo 3'te görüldüğü üzere son üç yılda șirketlerin 17'si stoklarının finansal tablolarda gösterimi için net gerçekleșebilir değeri kullanırken, $11^{\prime} \mathrm{i}$ ise maliyet değerini kullanmıștır. Șirketlerin stoklarını değerlemede kullandıkları değerler oransal olarak șekil 2'de gösterilmiștir.

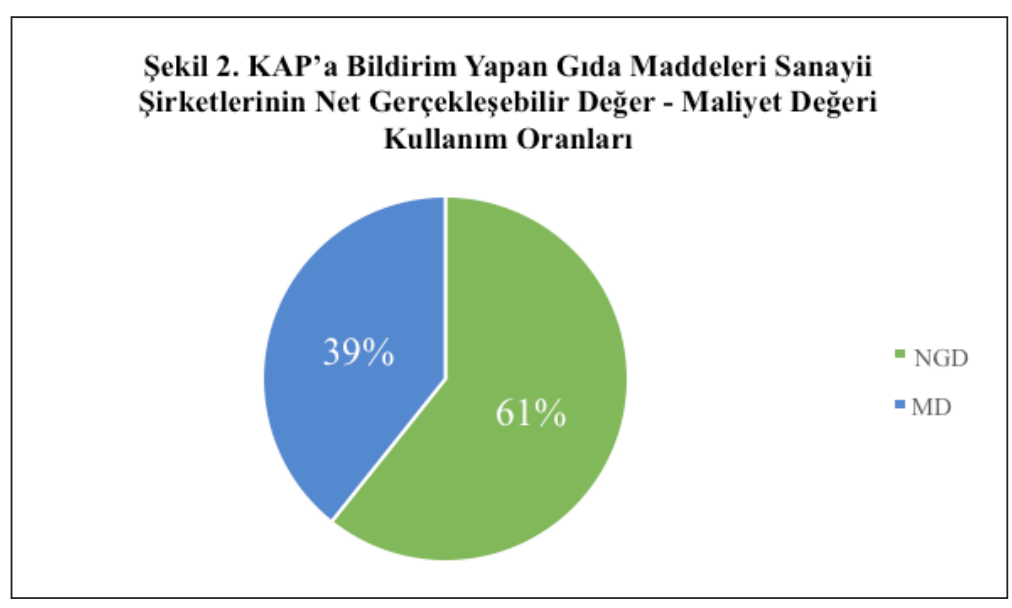

Șekil 2'de görüldüğü gibi KAP'a bildirim yapan gıda maddeleri sanayi șirketlerinin yaptıkları stok değerlemesi sonucunda \% 61 'i stoklarını finansal tablolarında net gerçekleșebilir değeriyle, \% 39'u ise maliyet değeri ile göstermiștir. Șirketler net gerçekleșebilir değeri kullanmaları ile birlikte, maliyet değeriyle net gerçekleșebilir değer arasındaki fark kadar stok değer düșüklüğü karșılığı ayırmaktadır. KAP'a bildirim yapan gıda maddeleri sanayi șirketlerinin stok değer düșüklügünün toplam stoklar içindeki payı tablo $4^{\prime}$ te gösterilmiștir.

\section{Tablo 4. KAP'a Bildirim Yapan Gida Maddeleri Sanayi Șirketlerinin Stok Değer Düșüklügünün Stoklara Oranı}

\begin{tabular}{|l|l|c|c|c|}
\hline ȘiRKET KODU & ȘíRKET ADI & $\mathbf{2 0 1 4}$ & $\mathbf{2 0 1 3}$ & $\mathbf{2 0 1 2}$ \\
\hline ALYAG & ALTINYAĞ & 0,71 & 2,71 & 2,94 \\
\hline AVOD & A.V.O.D. GIDA VE TARIM & 0,00 & 0,00 & 0,00 \\
\hline BANVT & BANViT & 0,09 & 0,25 & 0,65 \\
\hline CCOLA & COCA COLA IÇECEK & 0,71 & 1,31 & 0,89 \\
\hline DARDL & DARDANEL & 0,00 & 0,00 & 0,00 \\
\hline EKIZ & EKIZ KIMYA & 0,00 & 0,00 & 0,00 \\
\hline
\end{tabular}




\begin{tabular}{|l|l|c|c|c|}
\hline ERSU & ERSU GIDA & 0,00 & 3,20 & 0,60 \\
\hline FRIGO & FRiGO PAK GIDA & 1,88 & 2,37 & 2,83 \\
\hline KRSAN & KARSUSAN SU ÜRÜNLERi SAN. & 0,00 & 0,00 & 0,00 \\
\hline KENT & KENT GIDA & 31,57 & 21,19 & 72,49 \\
\hline KERVT & KEREVITAȘ GIDA & 0,18 & 0,19 & 0,28 \\
\hline KNFRT & KONFRUT GIDA & 0,36 & 0,38 & 0,94 \\
\hline KRSTL & KRISTAL KOLA & 3,11 & 4,12 & 10,48 \\
\hline MANGO & MANGO GIDA & 0,00 & 0,00 & 0,00 \\
\hline MERKO & MERKO GIDA & $-1,34$ & 0,30 & 0,35 \\
\hline MRTGG & MERT GIDA & 16,48 & 0,10 & 0,33 \\
\hline OYLUM & OYLUM SINAI YATIRIMLAR & 0,00 & 0,00 & 0,00 \\
\hline PENGD & PENGUEN GIDA & 0,61 & 0,54 & 0,43 \\
\hline PETUN & PINAR ET VE UN & 0,00 & 0,00 & 0,00 \\
\hline PINSU & PINAR SU & 0,00 & 0,00 & 0,00 \\
\hline PNSUT & PINAR SÜT & 0,00 & 0,00 & 0,00 \\
\hline SELGD & SELÇUK GIDA & 3,51 & 22,96 & 24,11 \\
\hline TATGD & TAT GIDA & 0,61 & 0,94 & 0,12 \\
\hline TKURU & TAZE KURU GIDA & 0,00 & 0,00 & 0,00 \\
\hline TUKAS & TUKAȘ & 0,17 & 0,21 & 0,32 \\
\hline ULUUN & ULUSOY UN SANAYi & 0,07 & 0,00 & 0,00 \\
\hline ULKER & ÜLKER BISKÜVI & 1,67 & 2,42 & 4,91 \\
\hline VANGD & VANET GIDA & 6,03 & 0,00 & 0,00 \\
\hline
\end{tabular}

Tablo 4 'te stoklarını maliyet değeri ile değerleyen 11 șirketin stok değer düșüklüğü karșılığı ayırmadığından șirketin stok değer düșüklüğünün stoklara oranının " $O^{\prime}$ olduğu görülmektedir. Stoklarını net gerçekleșebilir değer ile değerleyen 17 șirketin 14'ünün stok değer düșüklüğünün stoklara oranı \%5'in altında kalırken, $3^{\prime}$ ünün ise \% $5^{\prime}$ in üzerinde çıkmıștır.

\section{Sonuç}

TMS 2 Stoklar Standardı kapsamında stok maliyeti hesaplama yöntemleri bașlığı altında; gerçek parti maliyet yöntemi, F.I.F.O. (ilk giren ilk çıkar) maliyet yöntemi ve ağırlıklı ortalama maliyet yöntemleri yer almaktadır.

İșletmeler gerçek parti maliyet yöntemi ile belirlenecek stokları dıșındaki stok kalemleri için F.I.F.O. veya ağırlıklı ortalama maliyet yöntemlerini kullanabilmektedir. Ağırlıklı ortalama maliyet 
yöntemleri de dönem sonu ağırlıklı ortalama veya hareketli ortalama maliyet yöntemleri olarak uygulanabilmektedir.

Araștırma kapsamındaki 28 șirketin 2012 yılında 17'si ağırlıklı ortalama maliyet yöntemini (standartta yer alan dönem sonu ağırlıklı ortalama maliyet yöntemi), 5'i hareketli ortalama maliyet yöntemini ve $3^{\prime}$ ü ilk giren ilk çıkar maliyet yöntemini ve kullanmıștır. Șirketlerden 3 'ü ise kullandığı stok maliyeti hesaplama yöntemini açıklamamıștır. 2013 yılında șirketlerden 16'sı ağırlıklı ortalama maliyet yöntemini, 6'sı hareketli ortalama maliyet yöntemini ve 3'ü ilk giren ilk çıkar maliyet yöntemini kullanmıștır. Șirketlerden 3 'ü ise kullandığı stok maliyeti hesaplama yöntemini açıklamamıștır. 2014 yılında ise șirketlerden $15^{\prime} \mathrm{i}$ ağırlıklı ortalama maliyet yöntemini, $4^{\prime}$ ü ilk giren ilk çıkar maliyet yöntemini ve $4^{\prime}$ 'ü ise hareketli ortalama maliyet yöntemini kullanmıștır. Șirketlerden $5^{\prime} \mathrm{i}$ ise kullandığı stok maliyeti hesaplama yöntemini açıklamamıștır.

Araștırma sonucunda en çok tercih edilen yöntemin dönem sonu ağırlıklı ortalama maliyet yöntemi (ortalama \%57) olduğu tespit edilmiștir. Bu yöntem diğer yöntemlere göre daha basit olduğundan uygulamada yaygın olarak kullanıldığı düșünülmektedir.

Gıda maddeleri sanayisinde kullanılan ilk madde ve malzeme, yarı mamullerin ve üretilen mamullerin sınırlı tüketim ömürleri bulunmaktadır. Dolayısıyla, ilk satın alınan ilk madde ve malzemenin öncelikle üretime alındığı, dönem bașı yarı mamullerin öncelikle mamule dönüștürüldüğü ve ilk üretilen mamullerin önce satıldığı göz önünde bulundurulmalıdır. Dönem sonu stoklarında ise, en son satın alınan ilk madde ve malzemeler, yarı mamuller ve dönem sonuna yakın tarihlerde üretilmiș mamuller yer almaktadır. Bu nedenle gıda sanayi sektöründeki șirketlerin yaptıkları faaliyetin fiili iș akıșına en uygun yöntemi, yani F.I.F.O. (ilk giren ilk çıkar) maliyet yöntemini uygulamaları finansal tabloların daha güvenilir, șeffaf ve gerçeğe uygun sunum özelliklerine sahip olmasını sağlayacaktır.

TMS 2 standardı kapsamında stokların değerlemesi maliyet bedeli ve net gerçekleșebilir değerden düșük olanı ile yapılmaktadır. Araștırma kapsamında șirketlerin 2012, 2013 ve 2014 yıllarına ait finansal durum tabloları incelendiğinde șirketlerin \% 61 'inde her üç yılda da stok değer düșüklüğü karșılığı bulunduğu, 
șirketlerin \% 39'unda ise stok değer düșüklüğü karșilığı bulunmadığı tespit edilmiștir. Araștırma kapsamındaki șirketlerin gıda sanayi sektöründe faaliyet gösterdiği dikkate alındığında, șirketlerin ilk madde ve malzeme, yarı mamul ve mamul stoklarının saklama, depolama ve tüketim ömürlerinin sınırlı olması nedenleriyle, bu șirketlerin stoklarında net gerçekleșebilir değerin maliyet değerinin alında yer alacak stokların bulunması doğaldır. Ancak șirketlerin \% 39'unda stokların herhangi bir nedenle değer düșüklüğüne uğramadığı șeklindeki finansal raporlama, finansal tablo kullanıcılarını yanılıcı bilgi verilmesine neden olabilecektir.

\section{KAYNAKLAR}

Akın H. ve F. Kurșunel. 2010. TMS-2'ye Göre Stokların Değerlemesinde Özellik Arz Eden Durumlar. Selçuk Üniversitesi Sosyal Bilimler MYO Dergisi 13 (1): $311-330$.

Alfredson K., K. Leo, R. Picker, P. Pacter ve J. Radford. 2005. Applying International Accounting Standards. Australia: John Wiley,

Badem C. ve C. Y. Özbey. 2013. Tam Maliyet ile Normal Maliyet Yöntemlerinin TMS 2 Stoklar Standardı Ile VUK Açısından Karșılaștırması ve Muhtemel Ertelenmiș Vergi Etkisi. Muhasebe ve Vergi Uygulamaları Dergisi 2: 65-92.

Bahadır O. 2012. Stoklarda Değerleme: UFRS/TFRS ve Vergi Mevzuatı Açısından. Mali Çözüm Dergisi 109 (Ocak-Șubat): 51-67.

Elitaș C. 2014. Türkiye Muhasebe Standartları / Türkiye Finansal Raporlama Standartlarının Muhasebenin Genel Kabul Görmüș Temel Kavramları Açısından Durumu. Muhasebe Bilim Dünyası Dergisi 16 (3): 113-126.

Gökçen G., B. Ataman ve C. Çakıcı. 2011. Türkiye Finansal Raporlama Standartları Uygulamaları: TFRS/TMS Özetleri ve Uygulamaları. İstanbul: BETA.

Özbek C. Y. 2008. Türkiye Muhasebe Standardı (TMS-2) Stoklar. Muhasebe ve Denetime Bakıș Dergisi (24): 77-102.

Stowoly H., M. J. Lebas ve Y. Ding. 2013. Financial Accounting And Reporting: A Global Perspective, İngiltere: Cengage Learning.

The Institude Of Chartered Accounts of Pakistan. 2015. Financial Accounting And Reporting 1, United Kingdom: Emile Woolf International.

Uyar B. 2009. "TMS 2 - Stoklar" Standardı Üzerine Genel Bir Değerlendirme. Muhasebe ve Denetime Bakıș Dergisi (29): 131-144.

Yükçü S. ve S. Gönen. 2012. Muhasebe Politikaları, Muhasebe Tahminlerindeki Değișiklikler ve Hatalar Standardına Illișkin Uygulama Önerileri. Mali Çözüm Dergisi (1 14): 17-35. 